\title{
Firms' Financial and Real Responses to Credit Supply Shocks: Evidence from Firm-Bank Relationships in Germany ${ }^{*}$
}

\author{
Nadja Dwenger \\ Universität Hohenheim \\ and CESifo
}

\author{
Frank M. Fossen $\dagger$ \\ University of Nevada, Reno, \\ DIW Berlin and IZA
}

\author{
Martin Simmler \\ Oxford University Centre \\ for Business Taxation \\ and DIW Berlin
}

December 29, 2017

\begin{abstract}
:
We investigate the importance of firm-bank relationships for the international transmission of bank distress to the real economy. Using a large panel of matched financial statements of firms of all sizes and their relationship banks in Germany, we find that banks with losses from proprietary trading activities during the 2007/8 financial crisis decreased their lending, and that their firm customers responded by reducing real investment and employment. We document how different types of firms partially offset reduced credit supply by resorting to alternative financing sources.
\end{abstract}

Keywords: financial crisis; international contagion; credit crunch; relationship lending; investment; employment

JEL Classification: D22; D92; G01; G21; G31

\footnotetext{
* Acknowledgments: A previous version of this paper was entitled "From financial to real economic crisis: Evidence from individual firm-bank relationships in Germany". We thank Murillo Campello (the editor), the anonymous referee, Jochen Bigus, Gabriel Chodorow-Reich, Vincent Dekker, Stefania Garetto, Jochen Hundsdoerfer, Raj Iyer, Andrei Shleifer, Todd Sorensen, Sascha Steffen, Jeremy Stein, Viktor Steiner, participants at the 2016 Annual Meeting of the American Economic Association (AEA/ASSA) in San Francisco and the 2015 Annual Meeting of the German Economic Association in Münster, and seminar participants at DIW Berlin, ETH Zurich, Freie Universität Berlin, and Sveriges Riksbank for valuable comments. Nadja Dwenger conducted part of this research as a Visiting Researcher at Harvard University and Frank Fossen at the University of California, Santa Cruz. We also thank DIW Berlin, LMU-ifo Economics \& Business Data Center and Oxford University for providing us with the data used in this paper.

${ }^{\dagger}$ Corresponding author, address: University of Nevada, Reno, Department of Economics, 1664 N. Virginia Street, Reno, NV 89557-0030, U.S.A., email: ffossen@unr.edu.
} 


\section{Introduction}

The aim of this paper is to investigate the role of firm-bank relationships for the transmission of financial shocks across continents and from the financial sector to the real sector of the economy. A better understanding of these transmission mechanisms is crucial for the design of effective policies in areas such as banking regulation and crisis management by central banks and governments.

We exploit the 2007/8 financial crisis as a quasi-experiment to analyze how credit supply shocks affect firms in Germany. In the first part of our analysis, we estimate to what extent reduced credit supply by its relationship banks impedes a firm's ability to borrow, to invest and to employ labor. In the second part, we investigate whether firms are able to mitigate a credit supply shock by adjusting the manner in which they finance their investments. We distinguish between types of firms according to the potential credit constraints they face as measured by their payout policy, age, size, asset tangibility, external financial dependency, and the number of existing banking relationships. We analyze to what extent these firms can resort to alternative financing sources, such as reducing dividends, using accumulated cash, issuing new equity, and establishing new banking relationships.

This paper makes four main contributions. First, we suggest a novel identification strategy based on proprietary trading losses. Second, we provide evidence from Germany, where firm-bank relationships are particularly important. Third, our sample includes a large number of small- and medium-sized firms, which are likely the most bank-dependent and yet understudied. Fourth, in addition to the effects of reduced credit supply on investment and employment, we provide evidence regarding how different types of firms are able to mitigate these effects.

As a novel identification strategy to disentangle credit supply from credit demand effects, we use individual banks' losses from their proprietary trading activities as an instrumental variable (IV) for banks' credit supply. We argue that this IV acts as a credit supply shifter for banks that is orthogonal to the credit demand of the firms that have prior relationships to these banks. During the 2007/8 financial crisis, losses from proprietary trading activities of banks in Germany were mostly due to their engagement in asset-backed securities in the United States. These proprietary trading losses of individual banks were unanticipated by banks (and even more so by firms) and unrelated to the business activities of the banks' firm customers. Since most banks in Germany are universal banks that are active in proprietary trading and 
commercial banking, large losses from proprietary trading may reduce a bank's equity base to a critically low level and thus spill over to a reduction in commercial lending.

Our IV approach allows us to take into account firms with only one relationship bank (see the discussion in De Jonghe et al. 2016; Degryse et al. 2017) without assuming identical demand effects within certain groups of firms. Our IV provides substantial variation at the individual bank level. ${ }^{1}$ We do not have to rely solely on the distinction between trading and non-trading banks but can also exploit variations in trading losses within the group of trading banks. Finally, by observing firm-bank relationships independent of loan applications, we account for firms that are discouraged from loan applications and thus likely to be the most credit-constrained. Thereby, our analysis extends prior studies based on loan or loan application data (Khwaja and Mian 2008; Jiménez et al. 2012, 2014; Amiti and Weinstein 2013; Iyer et al. 2014; Ioannidou et al. 2015; Paravisini et al. 2015; Bottero et al. 2016; Cingano et al. 2016; De Jonghe et al. 2016; Schiantarelli et al. 2016; Bentolila et al. 2017; Degryse et al. 2017). It also complements survey evidence regarding firms' difficulties in accessing the credit markets and discouraged loan applications (Campello et al. 2010; Popov and Udell 2012; Ongena et al. 2013; Beck et al. 2014).

Germany is a bank-based economy in which banking relationships are particularly important (Lahusen 2004). Before the 2007/8 crisis, the German economy was stable and there were no bubbles in the housing market, and during the crisis, changes in unemployment and other economic indicators were relatively moderate. Therefore, demand issues are a more manageable threat to identification in Germany than in other regions, such as eastern and southern European countries (Acharya et al. 2016) or eastern European countries and Turkey (Ongena et al. 2015). ${ }^{2}$ At the same time, the financial crisis affected many banks in Germany through their investment in US asset-backed securities (Bertaut et al. 2012).

The literature about the effects of credit supply shocks on firm outcomes in Germany is scarce. ${ }^{3}$ Berg (2016) analyzes loan applications from one major German bank and finds that loan rejections reduce investment and employment. We provide evidence based on $83 \%$ of all banks in Germany. Popov and Rocholl (2016), hereafter PR16, use the same firm financial

\footnotetext{
${ }^{1}$ This is in contrast to papers relying on regional or inter-industry variation (Ashcraft 2005; Dell'Ariccia et al. 2008; Greenstone et al. 2014) or dummy variables that characterize types of banks such as foreign banks from certain countries (e.g., Acharya et al. 2016), savings banks in certain regions (Popov and Rocholl 2016) or banks that are members of a trading platform (Abbassi et al. 2016).

${ }^{2}$ Ongena et al. (2015) also use firm-bank relationships, but we base our identification strictly on pre-existing firm-bank relationships and control for firm-fixed effects. We also add to their analysis by investigating the ability of firms to establish new banking relationships when they face a credit supply shock.

${ }^{3}$ Puri et al. (2011, 2017) are concerned with mortgage or consumer loans to retail customers.
} 
accounts database that we do, but no bank financial accounts, to analyze the effects of credit supply shocks on labor employment. We complete the picture by linking employment effects to financing and investment and show that capital is more credit sensitive than labor. Thus, a credit supply shock not only slows down economic growth but also changes production input ratios. ${ }^{4}$ We also document that employment reactions to credit supply shocks are larger in regions with high unemployment (likely due to lower costs of future replacement of layoffs) or low supply of publicly subsidized short-time work compensation.

The financial accounts data that we use include a large number of small- and mediumsized firms, which are likely the most bank-dependent and yet understudied. Parts of the literature rely on data from syndicated loans, which are typically used for large loans and therefore mostly involve large firms and banks (Ivashina and Scharfstein 2010; ChodorowReich 2014; Acharya et al. 2016). Credit registry data include small firms in some countries, such as Belgium and Spain (Jiménez et al. 2012, 2014; De Jonghe et al. 2016; Bentolila et al. 2017; Degryse et al. 2017). By using financial accounts data, we overcome a limitation of the German credit registry, which covers mostly very large enterprises because firms only have to report loans that exceed one million euros or $10 \%$ of eligible equity to the German Central Bank (Bundesbank 2017).

In addition to documenting the general vulnerability of firms to credit supply shocks, we study heterogeneity in firms' ability to mitigate the effects of credit supply shocks by resorting to internal financing, issuing new equity or establishing new banking relationships. The literature argues that different financing sources, such as debt and equity, are imperfect substitutes for certain types of firms (e.g., Kaplan and Zingales 1997; Rauh 2006). However, few papers empirically show how credit supply shocks affect the substitution of specific financing sources by different firms (Khwaja and Mian 2008; Popov and Udell 2012; Berg 2016).

\footnotetext{
${ }^{4}$ While PR16 provide difference-in-differences estimates for a specific credit supply shock, we estimate credit supply elasticities. Our identification strategy exploits variation at the individual bank level within Federal States and bank types, whereas PR16 rely on variation between Federal States and savings banks versus other types of banks.
} 


\section{Matched firm and bank panel data}

\subsection{Linking data via individual firm-bank relationships}

Our analysis focuses on the period from 2006 to 2010. Since our regressions include lagged control variables in first differences, we exploit data from 2004 to 2010. Our data consist of financial statements of non-financial firms in Germany from the database Dafne linked with the financial statements of each firm's relationship bank(s) from the database Bankscope (both provided by Bureau van Dijk). Due to publication requirements for corporations in Germany, Dafne covers the unconsolidated balance sheets and income statements of more than $85 \%$ of all incorporated firms in Germany since 2006, the majority of which are unlisted. Bankscope covers banks active in Germany and includes balance sheets and income statements, in addition to information on ownership, affiliated companies, and branches. A comparison with the German Bank Statistics provided by the German Central Bank reveals that Bankscope covers 83\% of all banks in Germany over our period of analysis.

We match bank and firm information based on the identification codes of 1-6 banks that firms annually report as their most important banks (Hausbanken). ${ }^{5}$ Although we do not observe whether the firms borrow from these banks, hold deposits, or use other services, it is likely that firms turn to these banks first if they desire a loan because they already share some information with them (Ongena et al. 2015, Popov and Rocholl 2016). We refer to these banks as the relationship banks of a firm. ${ }^{6}$ The average number of relationship banks per firm in our sample is 1.4, and the relationships are clearly sticky: only $3 \%$ of the firms in the sample swap a relationship bank for another, and less than $2 \%$ add or remove a relationship bank in a given year.

We drop the smallest firms with total assets worth less than 10,000 euros, in addition to firms in the real estate industry (these might have been directly affected by the subprime market crisis in the United States). After discarding outliers (the bottom and top 1\% in growth rates of liabilities and fixed assets), we are left with 291,079 firm-year observations with bank statements of their relationship banks from 2007 (or earlier) onwards including information on long-term lending. Table A1 in the Appendix provides summary statistics for the firms in our sample and their relationship banks.

\footnotetext{
${ }^{5}$ In their usual data distribution Bureau van Dijk only provides the most recent information on the relationship banks in Dafne, but we obtained the relationship banks that Bureau van Dijk had on file each year.

${ }^{6}$ If these firm-bank links reflect true firm-bank relationships with a measurement error, our estimates are lower bounds on the true effects.
} 


\subsection{Difference-in-differences}

Before we present our IV strategy, we preview initial evidence for the effects of the financial crisis on banks and firms in Germany. We first check in our data whether the 2007/8 crisis that originated in the United States was evident in the returns from proprietary trading of German banks. The data confirm that German banks incurred significant losses from proprietary trading in 2008 and that this year clearly stands out within our observation period 2004-2010 (see Figures O1 and O2 in Section 1 of the Online Appendix).

For an initial analysis of how banks’ proprietary trading losses affected firms' borrowing and real activity, we run difference-in-differences $(\mathrm{DiD})$ regressions, where the absolute value of proprietary trading losses of a firm's relationship bank(s) (scaled by a bank's financial assets excluding credit supplied) is interpreted as a continuous treatment intensity. If a firm has multiple relationship banks, we take the absolute value of negative average gains and losses. We expect firms whose relationship banks incur larger losses from proprietary trading to borrow less and potentially also to invest less and employ less labor. We also test for differential trends before the treatment in the spirit of a placebo test: proprietary trading losses of banks should be uncorrelated with firm behavior in the year prior to the loss. Any correlation prior to the loss would suggest the presence of endogenous matching between firms and banks or unobserved confounders. We include the share of trading banks in a firm's 2006 set of relationship banks interacted with time dummies in the regressions to control for potential differential time trends among firms with trading and non-trading banks and in some specifications additionally for industry and location dummies interacted with year dummies.

Table 1 shows the results. Firms whose relationship banks incurred larger losses from proprietary trading in the previous year (L. indicates lagged variables) exhibit lower growth rates in liabilities, fixed assets and employment. Liabilities and employment already react to a small extent in the year when the losses occur. The findings are consistent with a significant bank lending channel through relationship banks: banks lend less when they incur losses from proprietary trading, and this has financial and real economic consequences for their firm customers. Bank losses in the following year (F.) are not significantly correlated with any of the firm outcomes, which confirms that these losses are unanticipated by firms and that firms do not endogenously match up with banks according to the banks’ future trading losses. 
Table 1: Difference-in-differences estimations

\begin{tabular}{lllllll}
\hline \hline \multirow{2}{*}{ Dependent variable } & \multicolumn{2}{l}{ Liabilities, growth rate } & \multicolumn{2}{l}{ Fixed assets, growth rate } & \multicolumn{2}{l}{ Employment, growth rate } \\
\cline { 2 - 7 } & $(1)$ & $(2)$ & $(3)$ & $(4)$ & $(5)$ & $(6)$ \\
\hline F.Trading losses & -0.013 & 0.035 & -0.049 & -0.057 & 0.014 & 0.009 \\
& $(0.122)$ & $(0.096)$ & $(0.057)$ & $(0.056)$ & $(0.038)$ & $(0.045)$ \\
Trading losses & $-0.131^{* * *}$ & $-0.084^{*}$ & 0.004 & 0.006 & $-0.088^{* *}$ & $-0.076^{*}$ \\
& $(0.043)$ & $(0.044)$ & $(0.067)$ & $(0.058)$ & $(0.045)$ & $(0.043)$ \\
L.Trading losses & $-0.310^{* * *}$ & $-0.237^{* * *}$ & $-0.297^{* * *}$ & $-0.189^{* * *}$ & $-0.171^{* *}$ & $-0.144^{*}$ \\
& $(0.061)$ & $(0.049)$ & $(0.048)$ & $(0.040)$ & $(0.081)$ & $(0.084)$ \\
Industry $\times$ year dummies & & $\checkmark$ & & $\checkmark$ & $\checkmark$ & $\checkmark$ \\
Location $\times$ year dummies & & $\checkmark$ & & $\checkmark$ & $\checkmark$ & $\checkmark$ \\
Trading 05/06 × year int. & $\checkmark$ & $\checkmark$ & $\checkmark$ & $\checkmark$ & $\checkmark$ & 36,843 \\
Number of observations & 291,079 & 291,079 & 291,079 & 291,079 & 36,843 & \\
\hline
\end{tabular}

Notes: Estimations are at the firm level. The dependent variable is the growth rate in a firm's liabilities, fixed assets or employment, respectively. Trading losses are the absolute value of proprietary trading losses of a firm's relationship bank(s). F. indicates leads and L. lagged values. The standard errors reported in parentheses are clustered at the bank level. ***/**/* indicate significance at the $1 \% / 5 \% / 10 \%$ levels.

We also inspect time trends graphically and find common time trends in the lending behavior of trading and non-trading banks, in addition to common time tends in the investment behavior of their firm customers before the financial crisis (see Figures O3-O5 in the Online Appendix), which supports our identification strategy. Although trading banks are larger on average than non-trading banks due to a small number of very large trading banks (see Table A2 in the Appendix), the two bank types and their firm customers followed common trends. The graphs further show that credit supplied by trading banks fell drastically behind that of non-trading banks during the crisis in 2008, especially in terms of long-term credit. This result suggests a strong impact of proprietary trading losses on lending to firms.

In the next section, we discuss the IV strategy that we use to identify elasticities of firm borrowing, real investment, and employment with respect to the credit supply from relationship banks. In Section 4.3, we compare the estimated effect sizes from the DiD approach and our preferred IV approach.

\section{Methodological approach}

\subsection{Effects of credit supply on firm outcomes}

Our goal is to estimate the responses of firms to a contraction in credit supplied by their relationship banks. We expect effects on financing, investment and possibly employment if capital markets are imperfect and information asymmetries between firms and investors exist. If firms cannot fully compensate for a contraction in their relationship banks' loan supply by borrowing from other banks, the overall amount borrowed will decrease. Furthermore, if other sources of financing cannot fully substitute for the reduction in bank credit, firms will have to 
forego real investment opportunities and might reduce employment. To assess whether credit supply by relationship banks affects firm outcomes, consider the following model equation:

$$
\log \left(y_{i t}\right)=\beta_{0}+\beta_{1} \log \left(\text { credit supply }_{i, t-1}\right)+\beta_{2} t+\boldsymbol{\beta}_{\mathbf{3}}^{\prime} \boldsymbol{x}_{\boldsymbol{i t}}+\alpha_{\mathrm{ILSt}}+\delta_{i}+\varepsilon_{i t}
$$

where $i$ indicates firms and $t$ years. In the main estimations, the firm outcome variable $y_{i t}$ is one of the following: i.) amount of liabilities, ii.) stock of fixed assets (book values), or iii.) number of employees. We define the main explanatory variable credit supply $y_{i, t-1}$ as the lagged book value of all loans that a firm's relationship bank(s) grant to their customers (excluding inter-bank credits). ${ }^{7}$ The coefficient $\beta_{1}$ is of primary interest and represents an elasticity; $\beta_{1}>$ 0 implies that reduced credit supply from a firm's relationship banks reduces the firm's outcome. The growth rate of credit supply is endogenous, and we apply an IV approach to estimate the coefficients consistently, as we explain in Section 3.2.

We follow De Jonghe et al. (2016) and Degryse et al. (2017) and include industrylocation-size-time group dummies $\left(\alpha_{\text {ILSt }}\right)$ as time-varying controls for the credit demand of firms. To construct the dummy variables, we interact NACE 2-digit industry dummies, dummies for 38 administrative districts in Germany, firm size decile dummies based on the total assets of a firm, and year dummies. This results in 41,272 dummy variables in our main estimations. Note that we do not have to rely on the assumption that the industry-locationsize-time fixed effects effectively control for credit demand because we use an IV that we argue to be orthogonal to credit demand even without conditioning on these controls. That is, our IV strategy purges any demand effects from the regression. We include the controls to make the identification even more robust and credible (and exclude them in a robustness check).

The vector of further control variables $\boldsymbol{x}_{\boldsymbol{i t}}$ includes the firm-specific tax rate on business profits $^{8}$ and its first time lag. Furthermore, we control for firm size (total assets), a firm’s share of tangible assets in total assets, and a firm's number of relationship banks. We use the 2006 values of these variables interacted with year dummies because the contemporaneous values might be endogenous.

The model represented in eq. (1) includes unobserved firm fixed effects $\delta$ i. To avoid bias due to unobserved firm heterogeneity, we eliminate all time-invariant characteristics by first-

\footnotetext{
${ }^{7}$ Lagged credit supply accounts for the time lag between the date of agreement about a bank loan and the actual payment date. Our results are robust to including contemporaneous credit supply as a regressor (for which we estimate a small and insignificant coefficient).

${ }^{8}$ The tax rate includes the corporate income tax, the mandatory solidarity surcharge, and the local business tax. The rates of the latter vary across the more than 12,000 German municipalities.
} 
differencing eq. (1). Using $\log \left(y_{i t}\right)-\log \left(y_{i, t-1}\right) \approx \frac{\Delta y_{i t}}{y_{i, t-1}}$, the equation in first differences is written as

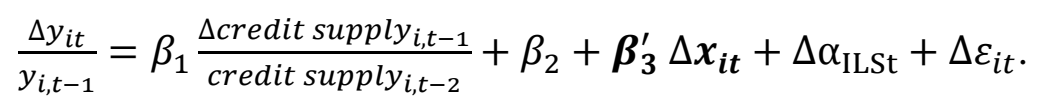

The dependent variable is the one-year growth rate in $y_{i t}$. In particular, if $y_{i t}$ is the capital stock, the dependent variable in eq. (2) is the real net investment relative to the stock of fixed assets. The key explanatory variable is the lagged growth rate in the credit volume that the firm's relationship banks lend to their customers. If a firm has more than one relationship bank, we take the average of the banks' growth rates. In the Online Appendix (Section 5), we report robustness checks on this choice. Throughout the paper, we report standard errors that are robust to clustering at the level of the relationship banks. ${ }^{9}$

\subsection{Endogeneity and IV approach}

We apply a two-stage least squares (2SLS) IV approach because the growth rate of credit supply is expected to be endogenous even after eliminating firm-fixed effects for four reasons. First, we observe the banks' loan volume, which is determined by supply and demand. Demand for credit, however, depends on a firm's investment opportunities, which are likely reduced during the crisis. This would yield a positive coefficient in an ordinary least squares regression of investment on credit growth even without a causal relationship. To isolate the supply effect from the demand effect, we require a supply shifter as an IV that correlates with the bank's credit supply but is independent from firms' credit demand.

Second, we do not observe the growth rate of the loans a relationship bank grants to a specific firm but rather the growth rate of the bank's total loans supplied to all its customers. This variable corresponds to the growth rate of loans granted to a specific firm measured with error. The IV method econometrically accounts for measurement error.

Third, we aim to identify the bank lending channel-that is, the transmission from decreasing bank credit supply to reduced firm borrowing, investment and employmentisolated from the firm balance sheet channel. The firm balance sheet channel describes reduced credit flow due to a devaluation of a firm's assets and thus of the collateral the firm can provide (cf. Jiménez et al. 2012). Because bank distress and devaluation of firms’ assets often occur simultaneously, we require an instrument that relates to a bank’s credit supply but is independent of its firm customers’ balance sheets.

\footnotetext{
${ }^{9}$ If a firm has several relationship banks, we use the relationship bank with the highest losses (lowest profits) from proprietary trading to define clusters.
} 
Fourth, firms may change their relationship banks in response to reduced credit supply. This endogenously changes the explanatory variable of interest, namely, the credit supplied by the current relationship banks. Therefore, we require an instrument that is independent of changes in the firm-specific set of relationship banks.

Our preferred instrument is the absolute value of losses from proprietary trading of the banks with which a given firm had a banking relationship in 2006 (before the crisis) scaled by the bank's financial assets (excluding credit supplied). In the main analysis, we code gains as zero losses, whereas in a robustness check, we treat gains and losses symmetrically. If a firm had more than one relationship bank in 2006, we take the average of their proprietary trading gains and losses, code average positive gains as zero, and take the absolute value. To avoid endogeneity through firms changing their relationship banks, we fix the firm-specific set of relationship banks as observed in 2006 (before the U.S. financial crisis hit) for all subsequent years when we construct the IV. If the information on the relationship banks is missing for a firm in 2006, we use the information from 2007 instead.

We expect the two requirements for the validity of the IV to hold, relevance and exogeneity. First, the IV explains a bank's lending behavior (relevance): banks incurring losses from proprietary trading experience a decline in their equity and reduce lending. ${ }^{10} \mathrm{We}$ test the strength of the IV in first-stage regressions and empirically confirm the relationship between proprietary trading losses and lending. Second, an individual bank's losses from proprietary trading are exogenous to individual firms: by definition, proprietary trading activities are the financial trading activities that a bank conducts on its own account and that are unrelated to business with its customers. Exogeneity is especially plausible in the context of the unexpected and sudden 2007/8 financial crisis.

Firms with trading relationship banks are larger on average compared to firms with nontrading banks. In our regressions, we therefore control for firm size interacted with year dummies. In terms of industry composition, debt ratio, and growth rate of liabilities before the crisis, firm customers of trading and non-trading banks are very similar (see Table A3 in the Appendix).

In robustness checks reported in Section 3 of the Online Appendix, we use three additional candidate IVs. The first follows Puri et al. (2011) and Popov and Rocholl (2016) and exploits the fact that some but not all savings banks were indirectly affected by the financial crisis through their ownership of specific Federal State Banks. The second additional

\footnotetext{
${ }^{10}$ Proprietary trading losses as reported in the German Commercial Code (HGB), which applies to $99.9 \%$ of the firms and banks in our sample, affect regulatory capital (Lachnit 2005).
} 
instrument draws on the idea that relationship banks with subsidiaries or branches in the United States were more exposed to the financial crisis. The third IV exploits membership of banks in Eurex Exchange as an indicator for active presence in securities markets (cf. Abbassi et al. 2016). The results with these additional instruments are in line with our main results reported below. Moreover, the availability of more than one excluded IV for one endogenous explanatory variable allows us to perform over-identification tests, which are passed in all specifications. In further robustness checks, we find that our results are robust to the scaling of our main instrument.

\section{Empirical results}

\subsection{Elasticity of firm liabilities}

Table 2 reports the results from estimating eq. (2) when we use the amount of a firm's liabilities as the outcome $y_{\mathrm{it}}$. The table shows that firm borrowing, in particular of long-term credit, depends on the credit supply from a firm's relationship banks. In column (1), we use losses from proprietary trading (in absolute values) as the instrument for credit supply. The coefficient $\beta_{1}$ of lagged credit supply is positive and significant at the $1 \%$ level. Interpreting $\beta_{1}$ as the elasticity in eq. (1), we find that a firm's liabilities decrease by $0.12 \%$ when its relationship banks contract credit supply by $1 \%$. 
Table 2: Credit supply from relationship banks affects firm liabilities

2SLS regressions of growth in firms' liabilities on growth in credit supply from relationship banks

\begin{tabular}{llll}
\hline \hline & $(1)$ & $(2)$ & $(3)$ \\
\hline L.Credit supply, growth rate & $0.122^{* * *}$ & & $0.128^{* * *}$ \\
& $(0.023)$ & $0.030)$ \\
L.Long-term credit supply, growth rate & & $(0.064)$ & \\
& & -0.089 & -0.143 \\
D.Business tax rate & -0.142 & $(0.326)$ & $(0.320)$ \\
& $(0.320)$ & -0.204 & -0.220 \\
L.D.Business tax rate & -0.225 & $(0.501)$ & $(0.488)$ \\
& $(0.490)$ & $\checkmark$ & $\checkmark$ \\
Industry-location-size-year fixed effects & $\checkmark$ & $\checkmark$ & $\checkmark$ \\
Tangibility in 2006 $\times$ year interactions & $\checkmark$ & $\checkmark$ & $\checkmark$ \\
\# relationship banks in 2006 x year interact. & $\checkmark$ & 291,079 & 291,079 \\
Number of observations & 291,079 & 0.02 & 0.07 \\
Shea's partial $R^{2}$ & 0.09 & 36.07 & 13.66 \\
$1^{\text {st }}$ stage $F$-statistic & 40.01 & Losses from & Gains and losses \\
Instrumental variable & Losses from & proprietary & from proprietary \\
& proprietary & trading & trading \\
\hline
\end{tabular}

Notes: Estimations are at the firm level. The dependent variable is the growth rate in a firm's liabilities. The growth rate of (long-term) credit supply pertains to a firm's relationship bank(s). D. indicates the first time difference of a variable and L. lagged values. The lagged (long-term) growth rate of credit supply is treated as endogenous. All regressions are 2SLS regressions using lagged proprietary trading losses (columns 1 and 2) or lagged proprietary trading gains and losses (column 3) of firms’ 2006 relationship banks as instruments. The standard errors reported in parentheses are clustered at the bank level. *** indicates significance at the $1 \%$ level.

We repeat the estimations with long-term credit supply (term of at least five years) as the main explanatory variable. Our results are qualitatively similar, but the estimated elasticity of 0.319 (column 2) is more than 2.5 times the size of the estimate we obtain for overall credit supply. Thus, firm borrowing is most sensitive to the amount of long-term credit that relationship banks supply. Short-term credit appears to be available more easily from other banks. ${ }^{11}$

Losses from proprietary trading are a strong instrument, as indicated by the first-stage statistics, which appear at the bottom of Table 2. The detailed first-stage results (reported in column 1 of Table A4 in the Appendix) show that banks that incur larger losses from proprietary trading reduce their lending volume more, as expected.

The first stage results also shed light on the mechanism that drives the correlation of proprietary trading losses and credit supply. First-stage results from alternative regressions with trading losses and gains show that trading losses, but not gains, are the main drivers of

${ }^{11}$ In an unreported specification, we use the growth rate in bank (instead of total) liabilities as the dependent variable. We find a similar point estimate (equal to 0.131), but it is imprecisely estimated and insignificant because we observe bank liabilities for 25,067 observations only (after trimming the 10\% most extreme growth rates). 
credit supply (see columns 2 and 3 of Table A4). Thus, not the trading activity per se but rather trading losses matter for credit supply. This result suggests that the correlation stems from the bank equity channel, not from banks shifting towards holding more securities to exploit arbitrage opportunities arising from fire sales during the crisis (Abbassi et al. 2016). Note that our instrument is valid with either of the two channels since both mechanisms are exogenous to a bank’s firm customers. Reassuringly, our estimated elasticity of firm liabilities with respect to credit supply remains virtually unchanged if we use trading gains and losses as instrument (column 3 of Table 2) instead of losses only. In what follows, we use trading losses as the stronger instrument.

Our results demonstrate that firms cannot fully replace credit supply from relationship banks by credit from other banks. Firm-bank relationships are thus an important determinant of firms' access to borrowed capital in bank-based economies such as Germany. This result is consistent with the characterization of sticky firm-bank relationships as a means to mitigate information asymmetries (Diamond 1991; Petersen and Rajan 1994; Harhoff and Körting 1998; Boot 2000; Degryse and Van Cayseele 2000) and with an important role of relationship banking in the transmission of monetary shocks (cf. Hachem 2011; Bolton et al. 2016). Sette and Gobbi (2015) report that banking relationships remain important during a financial crisis, but bank-borrower relationships make firms vulnerable if their particular relationship banks experience distress. We provide new evidence for this vulnerability. Prior theoretical work and empirical evidence find that collateral requirements decrease in the duration of a bankfirm relationship (Boot and Thakor 1994; Berger and Udell 1995; Degryse and Van Cayseele 2000), which may contribute to the difficulties that firms face when they need to switch banks. We further substantiate this argument in Section 4.4, where we report that firms with low tangibility of assets exhibit larger investment sensitivities to credit supply shocks.

The documented importance of (long-term) credit supply from relationship banks for firm borrowing raises the possibility of effects on the real economy through firms' investment and labor employment, which we analyze next.

\subsection{Elasticities of fixed assets and employment}

Table 3 presents our results from estimating eq. (2) when we use a firm’s capital stock as $y_{\text {it. }}{ }^{12}$ The table reveals significant investment and employment sensitivities, in particular with respect to long-term credit. The estimated elasticity of a firm's stock of fixed assets with

12 The first-stage regression is identical to that in the previous section. For employment, the number of observations is smaller, but the first-stage results are very similar. 
respect to lagged credit supply is significant at the $1 \%$ level and indicates that a reduction in credit supply by $1 \%$ reduces firm investment by $0.09 \%$ (column 1 ). Thus, firms cannot fully offset reduced credit supply from their relationship banks by using other financing sources and consequently reduce their real investment.

Table 3: Credit supply determines firms' real investment and employment

2SLS regressions of growth in fixed assets and employment on growth in credit supply from relationship banks

\begin{tabular}{|c|c|c|c|c|c|c|}
\hline \multirow[t]{2}{*}{ Outcome Variable } & \multicolumn{2}{|c|}{ Fixed Assets } & \multicolumn{2}{|c|}{ Number of Employees } & \multicolumn{2}{|c|}{ Employees/Fixed Assets } \\
\hline & (1) & (2) & (3) & (4) & (5) & (6) \\
\hline $\begin{array}{l}\text { L.Credit supply, } \\
\text { growth rate }\end{array}$ & $\begin{array}{l}0.091^{* * *} \\
(0.032)\end{array}$ & & $\begin{array}{l}0.063^{*} \\
(0.034)\end{array}$ & & $\begin{array}{l}-0.061^{* *} \\
(0.026)\end{array}$ & \\
\hline $\begin{array}{l}\text { L.Long-term credit } \\
\text { supply, growth rate }\end{array}$ & & $\begin{array}{l}0.238^{* * *} \\
(0.068)\end{array}$ & & $\begin{array}{l}0.170^{*} \\
(0.094)\end{array}$ & & $\begin{array}{l}-0.165 * * \\
(0.072)\end{array}$ \\
\hline D.Business tax rate & $\begin{array}{l}-0.365^{*} \\
(0.204)\end{array}$ & $\begin{array}{l}-0.326 \\
(0.206)\end{array}$ & $\begin{array}{l}-0.585 \\
(0.376)\end{array}$ & $\begin{array}{l}-0.566 \\
(0.371)\end{array}$ & $\begin{array}{l}0.356 \\
(0.285)\end{array}$ & $\begin{array}{l}0.338 \\
(0.283)\end{array}$ \\
\hline L.D.Business tax rate & $\begin{array}{l}-0.364 \\
(0.411)\end{array}$ & $\begin{array}{l}-0.349 \\
(0.422)\end{array}$ & $\begin{array}{l}0.277 \\
(0.320)\end{array}$ & $\begin{array}{l}0.267 \\
(0.315)\end{array}$ & $\begin{array}{l}0.019 \\
(0.335)\end{array}$ & $\begin{array}{l}0.029 \\
(0.329)\end{array}$ \\
\hline $\begin{array}{l}\text { Industry-location-size- } \\
\text { year fixed effects }\end{array}$ & $\checkmark$ & $\checkmark$ & $\checkmark$ & $\checkmark$ & $\checkmark$ & $\checkmark$ \\
\hline $\begin{array}{l}\text { Tangibility in } 2006 \times \\
\text { year interactions }\end{array}$ & $\checkmark$ & $\checkmark$ & $\checkmark$ & $\checkmark$ & $\checkmark$ & $\checkmark$ \\
\hline $\begin{array}{l}\text { \# relationship banks in } \\
2006 \times \text { year int. }\end{array}$ & $\checkmark$ & $\checkmark$ & $\checkmark$ & $\checkmark$ & $\checkmark$ & $\checkmark$ \\
\hline Number of observ. & 291,079 & 291,079 & 36,843 & 36,843 & 36,843 & 36,843 \\
\hline Shea’s partial $R^{2}$ & 0.09 & 0.02 & 0.10 & 0.02 & 0.10 & 0.02 \\
\hline $1^{\text {st }}$ stage $F$-statistic & 40.01 & 36.07 & 44.69 & 31.05 & 44.69 & 31.05 \\
\hline
\end{tabular}

Notes: Estimations are at the firm level. The dependent variable is the growth rate in a firm's fixed assets or employment or the ratio employees/fixed assets. The growth rate of (long-term) credit supply pertains to a firm's relationship bank(s). D. indicates the first time difference of a variable, and L. indicates lagged values. The lagged (long-term) growth rate of credit supply is treated as endogenous. All regressions are 2SLS regressions using lagged proprietary trading losses of firms' 2006 relationship banks as the instrument. We only include firms with more than four employees in the analysis of employment reactions. The standard errors reported in parentheses are clustered at the bank level. $* * * / * * / *$ indicate significance at the $1 \% / 5 \% / 10 \%$ levels.

When we use long-term credit supply (column 2) instead of total credit supply, we obtain a much larger estimate of the elasticity of a firm's fixed assets of 0.238 , which is in line with our findings regarding firm borrowing. The investment sensitivity to long-term credit supply is more than twice as large as the sensitivity to general credit supply, which is plausible given that real investment relies primarily on long-term funds.

What do the findings regarding real investment entail for employment? Do firms also reduce employment as the second major input factor of production when their relationship banks cut backing lending? This behavior is what we expect if capital and labor are complements. To answer this question, we re-estimate eq. (2), but with the number of employees as $y_{i t}$ (based on the subsample of firms with more than five employees reported; many firms do not provide this information). We find a positive effect of credit supply on the number of employees. The estimated elasticity in our baseline specification in column (3) is 
0.063, significant at the $10 \%$ level. ${ }^{13}$ Again, we see that the coefficient of interest increases when we consider long-term credit supply instead of overall credit supply (column 4). To test directly whether employment or fixed assets respond more strongly, we use the change of employment over fixed assets as the dependent variable in columns (5) and (6). The results show that a reduction in banks' credit supply increases firms' labor-to-capital ratio, which is in line with the smaller elasticity for employment compared to capital in our separate estimations. In Germany, we expect the sensitivity of employment to be lower than that of investment for two reasons: first, the government offers subsidized short-time work compensation schemes (Kurzarbeit) to buffer employment in economic downturns (see Hijzen and Venn 2011), and second, labor legislation puts tight restrictions on dismissals.

Our results for employment are qualitatively in line with the prior literature (e.g., Chodorow-Reich 2014; Acharya et al. 2016). We quantitatively compare our results to those of Popov and Rocholl (2016), who study the impact of a specific credit supply shock on employment in Germany. PR16 exploit that some savings banks were indirectly hit by the financial crisis through their ownership of certain Federal State Banks, which incurred large losses during the financial crisis. PR16 estimate that overall employment in Germany declined by 142,500 persons due to this shock to savings banks. Using the average increase in banks' losses from proprietary trading between 2007 and 2008 and our estimated elasticity, we estimate a loss of employment of 53,250 workers due to proprietary trading losses in Germany (see Section 4.3 for details). According to the Federal Employment Agency (2017), overall employment (including marginal employment) in Germany decreased by 66,616 employees between September 2008 and September 2009 and grew in 2008 and 2010. Given these employment figures, the estimate of PR16 is certainly at the upper end of the plausible range-in particular, as employment was most likely also reduced due to depressed demand for goods and services in 2009.

The strong identifying assumption PR16 need to make is that employment is unrelated to the choice of savings banks as relationship banks that are located in certain Federal States. The estimates in PR16 are biased if firms that chose these savings banks had a different trend in labor demand for reasons other than credit supply. Given that savings banks are limited in their regional lending activity to the region in which they are located ("regional principle"), it is likely that saving banks' composition of firm customers differs between regions and that firms’ labor employment trends correlate with local labor market conditions. This correlation

\footnotetext{
${ }^{13}$ We obtain similar results with growth rates in employment costs and employment costs to fixed assets as dependent variables.
} 
might also explain why the point estimate of their DiD coefficient for employment decreases by almost half when PR16 include region-year fixed effects.

To assess the importance of the local labor market and to deepen our analysis of the relationship between labor and capital, we split our sample by two important local labor market conditions at the county level. Our identification strategy allows for such a sample split because we exploit variation in credit supply shocks at the individual bank level within regions. The first dimension we consider is the pre-crisis local unemployment rate (in 2006). We expect the cost of finding new employees to be lower in regions where unemployment rates are high. If the cost of future replacement of layoffs is lower in high unemployment regions, laying off workers is relatively more attractive for firms in these regions, and we expect a larger impact of a credit supply shock on employment. The second dimension is the local supply of publicly subsidized short-time work compensation schemes, which are common in Germany. Here, we exploit the fact that the compensation schemes depend on the funding available at the local employment center. We split the sample according to the share of workers that receive this benefit at the county level in 2009. In regions where more funding is available and thus more workers receive short-time work compensation, we expect firms' cost of retaining workers to be lower and therefore a smaller number of layoffs during a credit crunch. ${ }^{14}$ The results are in line with our prediction (see Table A5 in the Appendix). Employment responses to credit supply shocks are significant only in high-unemployment regions and in regions with a low supply of short-time work compensation. In contrast, investment responds similarly in regions with low and high unemployment or short-time work compensation supply. Liabilities respond similarly in high- and low-unemployment regions but more strongly in regions with low supply of short-time work compensation. A possible explanation is that the subsidies distributed in high-supply regions facilitated borrowing from non-relationship banks.

These novel results highlight the role that local labor markets play in firms' employment reactions to credit supply shocks. Low local unemployment rates and short-time work compensation schemes mitigate the impact of credit supply shocks on employment. We further demonstrate that real investment responds significantly to credit supply shocks even in regions where employment remains stable.

\footnotetext{
${ }^{14}$ We obtain data on unemployment rates and shares of workers that received short-time work compensation at the county level from the Federal Agency for Cartography and Geodesy. Due to administrative reforms, these data are unavailable for Mecklenburg-West Pomerania, which leaves us with 386 counties.
} 


\subsection{Economic impact during the financial crisis}

To illustrate the size of the estimated economic effects, we use a back-of-the-envelope calculation and quantify the impact of bank losses from proprietary trading during the financial crisis on firms' borrowing, investment and employment in our sample. The average increase in losses from proprietary trading of the banks in our sample, scaled by financial assets, was 0.76 percentage points between 2007 and 2008 (an increase in the mean absolute value from $0.06 \%$ to $0.82 \%)$. Inserting this in the first-stage equation for long-term credit supply (column 4 of Appendix Table A4), we obtain $0.0076 \times-1.161=-0.0088$. This decrease in the growth rate of long-term credit supply caused by the financial crisis is almost as large as the average growth rate in the sample (2005-2010) of 1\% (Appendix Table A1, Panel A).

To quantify the effect of relationship banks' proprietary trading losses on firm borrowing, we multiply the reduction in long-term credit supply by our elasticity estimate for firm liabilities (column 2 of Table 2) and obtain $-0.0088 \times 0.319=-0.0028$. This value corresponds

$-47 \%$ of the average growth rate of liabilities (equal to $0.6 \%$ in the sample). Using the elasticity of investment (column 2 of Table 3), the effect of banks' proprietary trading losses on investment is -0.0021 , or $-19 \%$ of the average net real investment rate (equal to $1.1 \%$ in the sample). Based on the elasticity of employment (column 4 of Table 3), we obtain -0.0015 . Thus, through proprietary trading losses of relationship banks, the growth rate in employment decreased by $13 \%$ of the average growth rate (equal to $1.2 \%$ in the sample). Correspondingly, the decrease in employment was 53,250 workers $(=-0.0015 \times 35.5$ million employees including marginal employment in Germany in September 2008 according to the Federal Employment Agency, 2017). We obtain very similar estimates when we use total credit supply instead of long-term credit supply in the calculations and larger estimates when we weight by firm size.

The estimated effect sizes are similar to those obtained from our simple DiD approach in Section 2.2. Taking the contemporaneous and lagged effects together, the DiD coefficients in the specifications with controls imply that the financial crisis reduced the average growth rates in liabilities by $41 \%$, in fixed assets by $13 \%$ and in employment by $14 \%$. Evidently, the shock in credit supply propagated through firm borrowing to investment and employment but was mitigated on the way. 


\subsection{Effect heterogeneity and adjustment channels}

We complete our analysis by exploring how different types of firms respond to reduced credit supply. We first analyze whether investment sensitivities differ by firm types. We expect credit supply elasticities of investment to be larger for more credit-constrained firms. We use five commonly used proxies for the degree of financing constraints that a firm faces. According to the literature, credit constraints are expected to be more severe for nondividend-paying firms (e.g., Fazzari et al. 1998), small and young firms (e.g., Hadlock and Pierce, 2010), firms with low asset tangibility (e.g., Almeida and Campello 2007) and firms with high external financial dependency (e.g., Rajan and Zingales 1998). We define firms that paid out dividends in 2006 as dividend-paying firms (a fifth of the firms in our sample). For simplicity, we use the term dividends for the distribution of profits of corporations to their owners, but keep in mind that our sample is not limited to stock corporations. Regarding the other criteria, we split our sample at the respective sample medians in 2006. ${ }^{15}$

Furthermore, we analyze adjustment channels that firms use to mitigate a reduction in credit supply in the full sample and in the different subsamples of potentially constrained firms. In particular, we investigate whether firms resort to accumulated cash, cut back their dividend payments or issue new equity. We also observe when firms establish new banking relationships by adding a new bank or swapping an existing bank relationship for a new one. These firms can probably obtain financing from the new banking partner. Firms with initially only one relationship bank (70\% of the firms in our sample) presumably face high costs of maintaining banking relationships. When we estimate the probability of establishing a new banking relationship, we therefore distinguish between firms with initially one bank and firms with strictly more than one bank in 2006. We analyze the adjustment channels by estimating eq. (2) by 2SLS as previously, but with different dependent variables: the changes in nominal capital, cash, and dividend payments and an indicator variable that is one if a firm has a new relationship bank in a given year.

\footnotetext{
${ }^{15}$ Among non-dividend paying firms, the median age is 12 , the median size (total assets) is 600,000 euros, the median share of tangible assets in total assets is $22 \%$, and the median external financial dependency is $-0.17 \%$ (measured by the NACE 2-digit industry median of the fraction of capital expenditures not financed with cash flow from operations before 2008).
} 
Table 4: Firm heterogeneity and adjustment channels

2SLS regressions of growth in various outcomes on growth in credit supply from relationship banks

\begin{tabular}{|c|c|c|c|c|c|c|}
\hline \multirow{3}{*}{$\begin{array}{l}\text { Dependent variable: } \\
\text { [Sample share of firms] }\end{array}$} & \multirow{3}{*}{$\begin{array}{l}\begin{array}{l}\text { Investment } \\
\text { sensitivity }\end{array} \\
\text { Growth of } \\
\text { Fixed assets } \\
\text { (1) }\end{array}$} & \multicolumn{5}{|c|}{ Adjustment channels } \\
\hline & & \multicolumn{3}{|l|}{ Growth of } & \multicolumn{2}{|c|}{ New relation. bank } \\
\hline & & $\begin{array}{l}\text { Nominal } \\
\text { capital } \\
(2)\end{array}$ & $\begin{array}{l}\text { Cash } \\
\text { (3) }\end{array}$ & $\begin{array}{l}\text { Divi- } \\
\text { dends } \\
\text { (4) }\end{array}$ & $\begin{array}{l}1 \text { bank } \\
\text { in } 2006 \\
(5)\end{array}$ & $\begin{array}{l}>1 \text { banks } \\
\text { in } 2006 \\
(6)\end{array}$ \\
\hline \multicolumn{7}{|l|}{ Panel A: Full sample } \\
\hline Pooled effect & $\begin{array}{l}0.091^{* * *} \\
(0.032)\end{array}$ & $\begin{array}{l}-0.005 \\
(0.005)\end{array}$ & $\begin{array}{l}0.124^{*} \\
(0.063)\end{array}$ & $\begin{array}{l}0.118 \\
(0.100)\end{array}$ & $\begin{array}{l}-0.007 \\
(0.029)\end{array}$ & $\begin{array}{l}-0.177^{*} \\
(0.106)\end{array}$ \\
\hline \multicolumn{7}{|l|}{ Elasticities for } \\
\hline $\begin{array}{l}\text { Non-divid. paying firms } \\
\text { [81\%] }\end{array}$ & $\begin{array}{l}0.097 * * * \\
(0.035)\end{array}$ & $\begin{array}{l}-0.015^{* *} \\
(0.006)\end{array}$ & $\begin{array}{l}0.117 * \\
(0.071)\end{array}$ & & $\begin{array}{l}0.001 \\
(0.023)\end{array}$ & $\begin{array}{l}-0.125 \\
(0.083)\end{array}$ \\
\hline $\begin{array}{l}\text { Dividend paying firms } \\
\text { [19\%] }\end{array}$ & $\begin{array}{l}0.038 \\
(0.040)\end{array}$ & $\begin{array}{l}0.008 \\
(0.021)\end{array}$ & $\begin{array}{l}0.226 * \\
(0.126)\end{array}$ & $\begin{array}{l}1.023 * * * \\
(0.396)\end{array}$ & $\begin{array}{l}-0.057 \\
(0.071)\end{array}$ & $\begin{array}{l}-0.295^{* *} \\
(0.133)\end{array}$ \\
\hline $\begin{array}{l}\text { Panel B: Non-dividend payi } \\
\text { Elasticities by firm age }\end{array}$ & g firms only & & & & & \\
\hline $\begin{array}{l}\text { Elasticities by firm age } \\
\text { Young firms }\end{array}$ & $\begin{array}{l}0.122 * * * \\
(0.044)\end{array}$ & $\begin{array}{l}0.004 \\
(0.011)\end{array}$ & $\begin{array}{l}0.341^{* * *} \\
(0.116)\end{array}$ & & $\begin{array}{l}0.003 \\
(0.026)\end{array}$ & $\begin{array}{l}0.036 \\
(0.081)\end{array}$ \\
\hline Mature firms & $\begin{array}{l}0.018 \\
(0.044)\end{array}$ & $\begin{array}{l}-0.037 * * * \\
(0.007)\end{array}$ & $\begin{array}{l}-0.044 \\
(0.067)\end{array}$ & & $\begin{array}{l}0.004 \\
(0.024)\end{array}$ & $\begin{array}{l}-0.182 * * \\
(0.092)\end{array}$ \\
\hline \multicolumn{7}{|l|}{ Elasticities by firm size } \\
\hline Small firms & $\begin{array}{l}0.080 * * \\
(0.036)\end{array}$ & $\begin{array}{l}-0.007 \\
(0.006)\end{array}$ & $\begin{array}{l}0.229 * \\
(0.125)\end{array}$ & & $\begin{array}{l}-0.013 \\
(0.028)\end{array}$ & $\begin{array}{l}-0.213^{*} \\
(0.115)\end{array}$ \\
\hline Large firms & $\begin{array}{l}0.097 * * \\
(0.047)\end{array}$ & $\begin{array}{l}-0.029 * * \\
(0.012)\end{array}$ & $\begin{array}{l}0.051 \\
(0.118)\end{array}$ & & $\begin{array}{l}0.015 \\
(0.022)\end{array}$ & $\begin{array}{l}-0.078 \\
(0.074)\end{array}$ \\
\hline \multicolumn{7}{|l|}{ Elasticities by tangibility } \\
\hline Low tangibility & $\begin{array}{l}0.105^{*} \\
(0.054)\end{array}$ & $\begin{array}{l}-0.017 \\
(0.012)\end{array}$ & $\begin{array}{l}-0.022 \\
(0.084)\end{array}$ & & $\begin{array}{l}-0.010 \\
(0.015)\end{array}$ & $\begin{array}{l}-0.150 \\
(0.096)\end{array}$ \\
\hline High tangibility & $\begin{array}{l}0.061 \\
(0.041)\end{array}$ & $\begin{array}{l}-0.002 \\
(0.013)\end{array}$ & $\begin{array}{l}0.305^{*} \\
(0.170)\end{array}$ & & $\begin{array}{l}0.007 \\
(0.045)\end{array}$ & $\begin{array}{l}-0.123^{* * *} \\
(0.047)\end{array}$ \\
\hline \multicolumn{7}{|c|}{ Elasticities by external financial dependency } \\
\hline High dependency & $\begin{array}{l}0.154^{* * *} \\
(0.029)\end{array}$ & $\begin{array}{l}-0.016^{*} \\
(0.010)\end{array}$ & $\begin{array}{l}-0.045 \\
(0.110)\end{array}$ & & $\begin{array}{l}0.013 \\
(0.018)\end{array}$ & $\begin{array}{l}-0.193^{* * *} \\
(0.075)\end{array}$ \\
\hline Low dependency & $\begin{array}{l}0.057 \\
(0.043)\end{array}$ & $\begin{array}{l}-0.015^{*} \\
(0.008)\end{array}$ & $\begin{array}{l}0.168^{* * *} \\
(0.062)\end{array}$ & & $\begin{array}{l}-0.019 \\
(0.036)\end{array}$ & $\begin{array}{l}-0.086 \\
(0.091)\end{array}$ \\
\hline \multicolumn{7}{|c|}{ Elasticities by number of relationship banks } \\
\hline One bank in 2006 & $\begin{array}{l}0.097 * * * \\
(0.029)\end{array}$ & $\begin{array}{l}-0.021 \text { *** } \\
(0.007)\end{array}$ & $\begin{array}{l}0.149 * \\
(0.078)\end{array}$ & & & \\
\hline > 1 banks in 2006 & $\begin{array}{l}0.092 \\
(0.100)\end{array}$ & $\begin{array}{l}-0.033 \\
(0.021)\end{array}$ & $\begin{array}{l}-0.011 \\
(0.414)\end{array}$ & & & \\
\hline
\end{tabular}

Notes: Estimations are at the firm level. Each cell of the table pertains to a separate regression and indicates the elasticity of the outcome with respect to the lagged credit supply from a firm's relationship banks. The regressions follow eq. (2) and condition on our usual set of control variables, including industry-location-sizeyear fixed effects. The lagged growth rate of credit supply is treated as endogenous. All regressions are 2SLS regressions using lagged proprietary trading losses of firms' 2006 relationship banks as the instrument. For the calculation of the growth rate in dividends, we add 1 before taking the logarithm because otherwise, only dividend-paying firms would remain in our sample. In the estimations using the growth rate of cash as the dependent variable, we exclude firms with a growth rate of cash in the top or bottom $3 \%$ of the distribution. We split the sample at the median values of the firm characteristics. The standard errors reported in parentheses are clustered at the bank level. $* * * / * * / *$ indicate significance at the $1 \% / 5 \% / 10 \%$ levels.

Table 4 presents the results. The estimated elasticity of fixed assets with respect to credit supply of 0.091 in the full sample is driven by a relatively large elasticity of non-dividend paying firms (0.097). Within this group, the investment sensitivity is particularly large for 
young firms (0.12), firms with low asset tangibility (0.11), and firms with high external financial dependency (0.15). We find no significant difference between small and large firms. In summary, our results strongly support the view that investment sensitivities increase when credit constraints are more severe. The credit supply elasticity of investment decreases with the amount of pledgeable assets and the age of the firm, which appears to reduce information asymmetries in the capital market (Hadlock and Pierce 2010). Moreover, investment sensitivities are lower when firms can resort to cash flow from their own operations (as reflected in dividend payments and low external financial dependency).

Adjustment channels vary between firms. When faced with a credit supply shock, dividend-paying firms reduce dividends (column 4) and rely on available accumulated cash (column 3). Among the non-dividend paying firms, ${ }^{16}$ young firms, small firms, firms with a high share of tangible assets and firms with low external financial dependency use accumulated cash to finance their investments (column 3). The results for small and young firms are consistent with those of Almeida et al. (2004), who argue that firms at risk of facing financial constraints accumulate cash during good times as a buffer. While the evidence for cash-rich firms (low financial dependency) is not surprising, the result for firms with a high share of tangible assets might be. Our findings for these firms suggest that their pledgeable assets not only alleviate financial constraints (because these firms can receive funding in bad economic times) but also that their lower credit risk decreases their cash holding costs, leading to larger amounts of free cash. Furthermore, we find that mature and large firms are more likely to issue new equity when their relationship banks decrease credit supply, which is consistent with a comparably small degree of information asymmetries.

Regarding new banking relationships, our results suggest remarkable variation in the costs of establishing a new banking relationship across firms. In both the full sample and all sample splits, we find that only firms that had more than one relationship bank in 2006 form new banking relationships (adding or swapping banks) when the existing relationship banks reduce lending (columns 5 and 6). This option seems to be too expensive or difficult for firms with only one initial relationship bank, independent of standard observable firm characteristics, such as age, size, collateral, and financial dependency. This result informs us about the representativeness of papers that identify credit supply effects based on firm-time fixed effects and therefore have to rely on firms borrowing from multiple banks. Our results strengthen the important argument made by De Jonghe et al. (2016) and Degryse et al. (2017),

\footnotetext{
${ }^{16}$ Results for the full sample are similar, as discussed in Section 6 of the Online Appendix.
} 
who stress that it is crucial to understand the potentially very different behavior of firms with only one banking relationship. Instead of establishing new banking relationships, one-bank firms resort to accumulated cash when their single relationship bank decreases credit supply (bottom rows of the table). Due to the availability of this financial cushion, investment sensitivities seem to be similar among firms with one or more relationship banks, although the results for the latter group are imprecisely estimated.

Among the firms with more than one relationship bank in 2006, we find that the likelihood of establishing a new banking relationship differs between subgroups (column 6). Firms with a high external financial dependency, and thus with high demand for bank loans, are more likely to form new banking relationships when the existing relationship banks reduce lending. Mature firms with longer track record are also more likely to establish new banking relationships. This is consistent with evidence presented by De Jonghe et al. (2016), who show that banks allocate credit to low-risk firms at the expense of high-risk firms if hit by a negative funding shock. We further document that smaller firms are more likely to form new banking relationships. This result could be driven by bank behavior again, as banks can more easily hedge against idiosyncratic risks of smaller loans to smaller firms compared to larger loans to larger firms. Finally, we find that dividend-paying firms establish new banking relationships more often, which is again consistent with banks' low-risk allocation mechanism presented by De Jonghe et al. (2016): by paying dividends, firms signal having cash available and thus a lower default risk. ${ }^{17}$

To summarize, non-dividend-paying firms, younger firms, firms with low asset tangibility and firms with high external financial dependency reveal stronger investment sensitivity with respect to their relationship banks' credit supply. Almost all firm types are partially able to mitigate a contraction in credit supply, but there is substantial heterogeneity in the means of doing so. Dividend-paying firms cut back their payouts to finance investment, whereas mature and large firms issue new equity. Small and young firms rely on cash accumulated for this purpose, similar to firms with high asset tangibility and low external financial dependency do. Furthermore, we find that mature firms, small firms, dividendpaying firms and firms with high external financial dependency are more likely to establish a

\footnotetext{
${ }^{17}$ Our finding is also consistent with the outcome agency model of dividends by La Porta et al. (2000). The model predicts dividends to be paid out when strong minority shareholders pressure corporate insiders to disgorge cash, which may signal better corporate governance within a firm.
} 
new banking relationship when existent relationship banks reduce their credit supply, but only if they already had more than one relationship bank before the credit shortage. ${ }^{18}$

To provide an estimate of the relative importance of the different adjustment channels, we calculate the average amount of funds obtained from each financing source based on the point estimates for the full sample. When relationship banks reduce their credit supply by $10 \%$, firms decrease their cash holdings, on average, by 9660 euros $(0.1 \times 0.124 \times 779,000$ euros; cf. Table 4, pooled effect, and Table O7 in the Online Appendix), they reduce their dividend payments by 3434 euros $(0.1 \times 0.118 \times 291,000)$, and they externally raise new equity amounting to 361 euros $(0.1 \times 0.005 \times 722,000)$. In total, the additional self-financing amounts to 13,454 euros on average. In comparison, liabilities are reduced by 58,523 euros on average $(0.1 \times 0.122 \times 4,797,000$; cf. Table 2 and Appendix Table A1). Thus, on average, firms mitigate $23 \%$ of the reduction in debt financing through additional self-financing-by using (accumulated) cash (72\%), reducing dividends (25\%), and issuing new equity (3\%). Additionally, some firms partially adjust by obtaining loans from new banking partners.

\subsection{Potential endogenous matching and further robustness checks}

A potential concern with our identification strategy is endogenous matching between firms and banks. For example, firms with little investment opportunities might match up with certain banks, which then might be more likely to engage in proprietary trading due to missing lending opportunities. If investment of these firms slows down at the same time as their banks incur losses from proprietary trading, but without a causal relationship, our IV estimates could be biased. We address this concern by performing robustness checks. In the first, we only use firms with exactly one relationship bank in 2006 that engaged in proprietary trading. Endogenous matching as described above would imply that these firms have low investment opportunities and thus low financing needs. The variation exploited in this test originates entirely from variation in the scaled amount of losses from banks' proprietary trading. If sorting of firms to trading banks were driving our results, we would expect the estimated coefficients to drop. The results for firm liabilities, fixed assets and employment are presented in columns (1), (3) and (5) of Table 5. The point estimates are similar to the baseline estimates, which is evidence against endogenous sorting.

\footnotetext{
18 We also investigate whether the heterogeneity in investment sensitivities relates to heterogeneity in employment responses. For all our subsamples, the point estimates using the ratio employment to fixed assets as dependent variable are similar to the baseline estimation results presented in column 5 of Table 3 . The only exception is the group of firms with a high share of tangible assets, for which capital and employment are equally responsive.
} 
The second sensitivity test uses only firms with at least one trading and one non-trading relationship bank in 2006. Again, if sorting is driving the results, these firms are less likely to be selective because they have both a trading and a non-trading relationship bank. Since the number of observations is greatly reduced, we do not include the industry-location-size-year fixed effects but rather only industry-year, location-year and size-year fixed effects. The estimated elasticities shown in columns (2), (4) and (6) are greater but statistically indistinguishable from our baseline estimates. In the Online Appendix (Section 5), we additionally compare the elasticities for all firms that had only a single relationship bank in 2006 to those for all firms that had multiple banking relationships and find no significant differences. From all these tests, we conclude that endogenous matching between firms and banks does not explain our results and thus we are identifying effects of credit supply shocks.

In further robustness checks reported in the Online Appendix (Sections 2-4), we assess the sensitivity of our results with respect to the choice of control variables (with and without industry-location-size-time fixed effects) and alternative instruments and the definition of our sample. Our estimated elasticities are robust to all these specification choices. 


\section{Table 5: Firms with different constellations of relationship banks}

2SLS regressions of growth in liabilities, fixed assets and employment on growth in credit supply from relationship banks

\begin{tabular}{|c|c|c|c|c|c|c|}
\hline Dependent variable & \multicolumn{2}{|c|}{$\begin{array}{l}\text { Firm liabilities, } \\
\text { growth rate }\end{array}$} & \multicolumn{2}{|l|}{$\begin{array}{l}\text { Fixed assets, } \\
\text { growth rate }\end{array}$} & \multicolumn{2}{|c|}{$\begin{array}{l}\text { Number of employees, } \\
\text { growth rate }\end{array}$} \\
\hline Sample & $\begin{array}{l}\text { Firms with } \\
\text { a single } \\
\text { trading } \\
\text { bank in } \\
2006\end{array}$ & $\begin{array}{l}\text { Firms with } \\
\text { a trading } \\
\text { and a non- } \\
\text { trading } \\
\text { bank in } \\
2006\end{array}$ & $\begin{array}{l}\text { Firms with } \\
\text { a single } \\
\text { trading } \\
\text { bank in } \\
2006\end{array}$ & $\begin{array}{l}\text { Firms with } \\
\text { a trading } \\
\text { and a non- } \\
\text { trading } \\
\text { bank in } \\
2006\end{array}$ & $\begin{array}{l}\text { Firms with } \\
\text { a single } \\
\text { trading } \\
\text { bank in } \\
2006\end{array}$ & $\begin{array}{l}\text { Firms with } \\
\text { a trading } \\
\text { and a non- } \\
\text { trading } \\
\text { bank in } \\
2006\end{array}$ \\
\hline & (1) & (2) & (3) & (4) & (5) & (6) \\
\hline L.Credit supply, growth rate & $\begin{array}{l}0.136 * * * \\
(0.037)\end{array}$ & $\begin{array}{l}0.204^{* * *} \\
(0.075)\end{array}$ & $\begin{array}{l}0.078 * * \\
(0.035)\end{array}$ & $\begin{array}{l}0.067 \\
(0.048)\end{array}$ & $\begin{array}{l}0.065 \\
(0.057)\end{array}$ & $\begin{array}{l}0.104 \\
(0.095)\end{array}$ \\
\hline D.Business tax rate & $\begin{array}{l}0.722 \\
(0.447)\end{array}$ & $\begin{array}{l}0.418 \\
(0.604)\end{array}$ & $\begin{array}{l}-0.032 \\
(0.364)\end{array}$ & $\begin{array}{l}-0.709 \\
(0.476)\end{array}$ & $\begin{array}{l}-0.908 \\
(0.848)\end{array}$ & $\begin{array}{l}-0.091 \\
(0.428)\end{array}$ \\
\hline L.D.Business tax rate & $\begin{array}{l}0.551 \\
(0.655)\end{array}$ & $\begin{array}{l}-1.579 * * \\
(0.766)\end{array}$ & $\begin{array}{l}0.383 \\
(0.494)\end{array}$ & $\begin{array}{l}-1.770 * * \\
(0.848)\end{array}$ & $\begin{array}{l}0.563 \\
(1.221)\end{array}$ & $\begin{array}{l}-0.328 \\
(0.414)\end{array}$ \\
\hline Ind.-loc.-size-year fixed eff. & $\checkmark$ & & $\checkmark$ & & $\checkmark$ & \\
\hline Industry $\times$ year dummies & & $\checkmark$ & & $\checkmark$ & & $\checkmark$ \\
\hline Location $\times$ year dummies & & $\checkmark$ & & $\checkmark$ & & $\checkmark$ \\
\hline Size $\times$ year dummies & & $\checkmark$ & & $\checkmark$ & & $\checkmark$ \\
\hline Tangibility '06 × year int. & $\checkmark$ & $\checkmark$ & $\checkmark$ & $\checkmark$ & $\checkmark$ & $\checkmark$ \\
\hline \# relat. banks '06 × year int. & & $\checkmark$ & & $\checkmark$ & & $\checkmark$ \\
\hline Number of observations & 106,941 & 49,747 & 106,941 & 49,747 & 6564 & 9540 \\
\hline Shea's partial $R^{2}$ & 0.11 & 0.07 & 0.11 & 0.07 & 0.10 & 0.09 \\
\hline $1^{\text {st }}$ stage $F$-statistic & 25.05 & 18.87 & 25.05 & 18.87 & 15.35 & 24.58 \\
\hline
\end{tabular}

Notes: Estimations are at the firm level using the subsamples of firms with a single relationship bank that engaged in proprietary trading in 2006 or with at least one relationship bank that traded and one that did not trade in 2006. The dependent variable is the growth rate in a firm's liabilities, fixed assets or employment, respectively. The growth rate of credit supply pertains to the firm's relationship bank(s). D. indicates the first time difference of a variable, and $\mathrm{L}$. indicates lagged values. The lagged growth rate of credit supply is treated as endogenous. All regressions are 2SLS regressions using lagged proprietary trading losses of firms' 2006 relationship banks as the instrument. The standard errors reported in parentheses are clustered at the bank level. ***/** indicate significance at the $1 \% / 5 \%$ levels.

\section{Conclusion}

We investigate the international transmission of financial shocks to the real economy using German financial accounts data that allow us to observe a firm's financial, investment and employment decisions together with information about its relationship bank(s) over the period 2004-2010. Our sample includes unlisted small firms, which may be the firms most vulnerable to a contraction in loan supply. For identification we exploit variation in losses from proprietary trading that the relationship banks of individual firms in Germany incurred during the 2007/8 U.S. financial crisis.

Our results indicate that banks that incur larger losses from proprietary trading activities lend less to their customers. This is plausible because most banks in Germany are universal banks that are active in both proprietary trading and commercial banking. Thus, substantial 
losses from proprietary trading may reduce a bank’s equity base to a critically low level and spill over to commercial lending.

We document that firms whose relationship banks decrease their credit supply reduce the total amount they borrow from banks. This result demonstrates that relationship banking is important in Germany, as firms cannot easily substitute loans from a relationship bank with loans from other banks. We further find that these firms reduce real investment and employment. Thus, firms cannot completely offset the reduction in credit supply by using other forms of financing either. Low local unemployment rates and public short-term work compensation schemes mitigate the impact of credit supply shocks on employment. The effects that we measure are economically significant. We estimate that due to proprietary trading losses of German banks in 2007/8, the average growth rates of firms' external debt fell by $47 \%$, of real net investment by $19 \%$, and of employment by $13 \%$ relative to the sample averages (2005-2010).

We provide evidence for considerable heterogeneity in firms' ability to mitigate contractions in credit supply and in the adjustment channels that they use. Investment of firms that paid out dividends before the crisis responds less to credit supply shocks; instead, these firms reduce dividends and resort to internal financing. Investment sensitivities are also smaller for firms with more pledgeable assets - these firms can borrow from banks without a prior lending relationship more easily and seem to face comparably low cash holding costs. In contrast, investment of young firms is more responsive, which is consistent with information asymmetries. While young and small firms rely on precautionary accumulated cash to compensate partially for reduced credit supply, mature and large firms are more likely to issue new equity, capitalizing on their access to the equity market.

We complete our analysis of financial adjustment channels by demonstrating that not only mature firms and dividend-paying firms but also small firms and firms with high external financial dependency are more likely to establish a new banking relationship when hit by a credit supply shock. However, we document that this result only applies to firms with more than one banking partner to begin with; one-bank firms appear unable to establish new banking relationships, independent of the aforementioned firm characteristics.

For the economic modeling and policy management of crises, our results demonstrate the importance of the bank lending and firm borrowing channel in the development of a real economic crisis in a bank-based economy. By documenting the risk of international transmission of financial shocks through globalized banking, our analysis also informs the policy debate on banking regulation. In the current system of universal banks in countries 
such as Germany, a separation of investment banking from commercial banking would reduce the contagion risk from a financial crisis to a crisis in the real economy. On the other hand, universal banking might facilitate diversification of risks in other economic situations.

\section{References}

Abbassi, P., Iyer, R., Peydró, J.-L., Tous, F.R., 2016. Securities Trading by Banks and Credit Supply: Micro-Evidence from the Crisis. Journal of Financial Economics 121, 569-594.

Acharya, V., Eisert, T., Eufinger, C., Hirsch, C., 2016. Real Effects of the Sovereign Debt Crisis in Europe: Evidence from Syndicated Loans. Working Paper, DOI: 10.2139/ssrn.2612855.

Almeida, H., Campello, M., 2007. Financial Constraints, Asset Tangibility, and Corporate Investment. Review of Financial Studies 20, 1429-1460.

Almeida, H., Campello, M., Weisbach, M.S., 2004. The Cash Flow Sensitivity of Cash. Journal of Finance 59, 1777-1804.

Amiti, M., Weinstein, D., 2013. How Much Do Bank Shocks Affect Investment? Evidence from Matched Bank-Firm Loan Data. NBER Working Paper No. 18890, forthcoming in: Journal of Political Economy.

Ashcraft, A.B., 2005. Are Banks Really Special? New Evidence from the FDIC-Induced Failure of Healthy Banks. American Economic Review 95, 1712-1730.

Beck, T., Degryse, H., De Haas, R., Horen, N.V., 2014. When Arm's Length is Too Far Relationship Lending over the Credit Cycle. Bank of Finland Discussion Paper 14-2014, forthcoming in: Journal of Financial Economics.

Bentolila, S., Jansen, M., Jiménez, G., 2017. When Credit Dries Up: Job Losses in the Great Recession. Journal of the European Economic Association, DOI: 10.1093/jeea/jvx021.

Berg, T., 2016. Got Rejected? Real Effects of Not Getting a Loan. European Central Bank Working Paper No 1960.

Berger, A.N., Udell, G.F., 1995. Relationship Lending and Lines of Credit in Small Firm Finance. Journal of Business 68, 351-381.

Bertaut, C., DeMarco, L.P., Kamin, S., Tyron, R., 2012. ABS Inflows to the United States and the Global Financial Crisis. Journal of International Economics 88, 219-234.

Bolton, P., Freixas, X., Gambacorta, L., Mistrulli, P.E., 2016. Relationship and Transaction Lending in a Crisis. Review of Financial Studies 29, 2643-2676.

Boot, A., 2000. Relationship Banking: What Do We Know? Journal of Financial Intermediation 9, 7-25. 
Boot, A., Thakor, A.V., 1994. Moral Hazard and Secured Lending in an Infinitely Repeated Credit Market Game. International Economic Review 35, 899-920.

Bottero, M., Lenzu, S., Mezzanotti, F., 2016. Sovereign Debt Exposure and the Bank Lending Channel: Impact on Credit Supply and the Real Economy. Working Paper, http://home.uchicago.edu/ lenzus/real_effects_suppy_shock_BLM_apr282016.pdf.

Bundesbank, 2017. Monitoring Lending Business, Particularly Large Exposures and Loans of $€ 1.0$ Million or More. https://www.bundesbank.de/Navigation/EN/Tasks/ Banking_supervision/Lending_business/lending_business.html.

Campello, M., Graham, J.R., Harvey, C., 2010. The Real Effects of Financial Constraints: Evidence from a Financial Crisis. Journal of Financial Economics 97, 470-487.

Cingano, F., Manaresi, F., Sette, E., 2016. Does Credit Crunch Investment Down? New Evidence on the Real Effects of the Bank-Lending Channel. Review of Financial Studies 29, 2737-2773.

Chodorow-Reich, G., 2014. The Employment Effects of Credit Market Disruptions: FirmLevel Evidence from the 2008-9 Financial Crisis. Quarterly Journal of Economics 129, 159.

Degryse, H., De Jonghe, O., Jakovljević, S., Mulier, K., Schepens, G., 2017. Identifying Credit Supply Shocks with Bank-Firm Data: Methods and Applications. Working paper available at SSRN: https://ssrn.com/abstract=2788512.

Degryse, H., Van Cayseele, P., 2000. Relationship Lending within a Bank-Based System: Evidence from European Small Business Data. Journal of Financial Intermediation 9, 90109.

De Jonghe, O., Dewachter, H., Mulier, K., Ongena, S., Schepens, G., 2016. Some Borrowers are More Equal than Others: Bank Funding Shocks and Credit Reallocation. Working paper available at SSRN: https://ssrn.com/abstract=2774441.

Dell’Ariccia, G., Detragiache, E., Rajan, R., 2008. The Real Effect of Banking Crises. Journal of Financial Intermediation 17, 89-112.

Diamond, D.W., 1991. Monitoring and Reputation: The Choice between Bank Loans and Directly Placed Debt. Journal of Political Economy 99, 688-721.

Fazzari, S.M., Hubbard, G., Petersen, B., Blinder, A., Poterba, J., 1988. Financing Constraints and Corporate Investment. Brookings Papers on Economic Activity 1, 141-195.

Federal Employment Agency, 2017. Zeitreihe über Beschäftigte nach Altersgruppen (Monatszahlen). http://statistik.arbeitsagentur.de.

Greenstone, M., Mas, A., Nguyen, H.-L., 2014. Do Credit Market Shocks Affect the Real Economy? Quasi-experimental Evidence from the Great Recession and 'Normal' Economic Times. NBER Working Paper No. 20704. 
Hachem, K., 2011. Relationship Lending and the Transmission of Monetary Policy. Journal of Monetary Economics 58, 590-600.

Hadlock, C.J., Pierce, J.R., 2010. New Evidence on Measuring Financial Constraints: Moving Beyond the KZ Index. Review of Financial Studies 23, 1909-1940

Harhoff, D., Körting, T., 1998. Lending Relationships in Germany-Empirical Evidence from Survey Data. Journal of Banking and Finance 22, 1317-1353.

Hijzen, A., Venn, D., 2011. The Role of Short-Time Work Schemes during the 2008-09 Recession. OECD Social, Employment and Migration Working Paper No. 115.

Ioannidou, V., Ongena, S., Peydró, J.-L., 2015. Monetary Policy, Risk-Taking, and Pricing: Evidence from a Quasi-Natural Experiment. Review of Finance 19, 95-144.

Ivashina, V., Scharfstein, D., 2010. Bank Lending During the Financial Crisis of 2008. Journal of Financial Economics 97, 319-338.

Iyer, R., Peydró, J.-L., da-Rocha-Lopes, S., Schoar, A., 2014. Interbank Liquidity Crunch and the Firm Credit Crunch - Evidence from the 2007-2009 Crisis. Review of Financial Studies 27, 347-372.

Jiménez, G., Ongena, S., Peydró, J.-L., Saurina, J., 2012. Credit Supply and Monetary Policy: Identifying the Bank Balance-Sheet Channel with Loan Applications. American Economic Review 102, 2301-2326.

Jiménez, G., Ongena, S., Peydró, J.-L., Saurina, J., 2014. Hazardous Times for Monetary Policy: What Do Twenty-Three Million Bank Loans Say About the Effects of Monetary Policy on Credit Risk-Taking? Econometrica 82, 463-505.

Kaplan, S.N., Zingales, L., 1997. Do Financing Constraints Explain Why Investment Is Correlated with Cash Flow? Quarterly Journal of Economics 62, 169-215.

Khwaja, A.I, Mian, A., 2008. Tracing the Impact of Bank Liquidity Shocks: Evidence from an Emerging Market. American Economic Review 98, 1413-1442.

Lachnit, L., 2005. Other Comprehensive Income nach HGB, IFRS und US-GAAP Konzeption und Nutzung im Rahmen der Jahresabschlussanalyse. Der Betrieb 58, 16371645.

Lahusen, R., 2004. US-Unternehmen kapitalmarktorientierter. Deutsche Bank Research.

La Porta, R., Lopez-de-Silanes, S., Shleifer, A., Vishny, R., 2000. Agency Problems and Dividend Policies around the World. Journal of Finance 55, 1-33.

Ongena, S., Peydró, J.-L., Van Horen, N., 2015. Shocks Abroad, Pain at Home? Bank-FirmLevel Evidence on the International Transmission of Financial Shocks. IMF Economic Review 63, 698-750. 
Ongena, S., Popov, A., Udell, G., 2013. “When the Cat’s Away the Mice Will Play”: Does Regulation at Home Affect Bank Risk-taking Abroad? Journal of Financial Economics 108, 727-750.

Paravisini, D., Rappoport, V., Schnabl, P., Wolfenzon, D., 2015. Dissecting the Effect of Credit Supply on Trade: Evidence from Matched Credit-Export Data. Review of Economic Studies 82, 333-359.

Petersen, M., Rajan, R., 1994. The Benefits of Lending Relationships: Evidence from Small Business Data. Journal of Finance 49, 3-37.

Popov, A., Rocholl, J., 2016. Do Credit Shocks Affect Labor Demand? Evidence for Employment and Wages during the Financial Crisis. Journal of Financial Intermediation, DOI: 10.1016/j.jfi.2016.10.002.

Popov, A., Udell, G., 2012. Cross-Border Banking, Credit Access, and the Financial Crisis. Journal of International Economics 87, 147-161.

Puri, M., Rocholl, J., Steffen, S., 2011. Global Retail Lending in the Aftermath of the US Financial Crisis: Distinguishing Between Supply and Demand Effects. Journal of Financial Economics 100, 556-578.

Puri, M., Rocholl, J., Steffen, S., 2017. What Do a Million Observations Have to Say About Loan Defaults? Opening the Black Box of Relationships. Journal of Financial Intermediation 31, 1-15.

Rajan, R., Zingales, L., 1998. Financial Dependence and Growth. American Economic Review 88, 559-586.

Rauh, J., 2006. Investment and Financing Constraints: Evidence from the Funding of Corporate Pension Plans. Journal of Finance 61, 33-71

Schiantarelli, F., Stacchini, M., Strahan, P.E., 2016. Bank Quality, Judicial Efficiency and Borrower Runs: Loan Repayment Delays in Italy. NBER Working Paper No. 22034.

Sette, E., Gobbi, G., 2015. Relationship Lending During a Financial Crisis. Journal of the European Economic Association 13, 453-481. 


\section{Appendix}

Table A1: Summary statistics (2006-2010)

Mean Median Std. dev.

\section{Panel A: Firm data}

Dependent variables

Fixed assets in th. euros

Fixed assets, growth rate

$\begin{array}{lll}2183 & 72 & 69,317 \\ 0.011 & -0.054 & 0.431 \\ 4797 & 280 & 155,648 \\ 0.006 & -0.007 & 0.498 \\ 202 & 63 & 1695 \\ 0.012 & 0 & 0.164\end{array}$

Liabilities, growth rate

Number of employees $(N=36,843)$

Number of employees, growth rate $(N=36,843)$

0.012

0.164

Variables on relationship banks

Number of relationship banks

$\begin{array}{lll}1.404 & 1 & 0.684 \\ 0.172 & 0 & 0.346 \\ 0.002 & 0 & 0.010 \\ 0.024 & 0.017 & 0.117 \\ 0.010 & 0.005 & 0.220\end{array}$

然

Absolute value of losses from proprietary trading to financial assets

Avg. growth rate in credit supply from relationship banks

0.010

0.005

0.220

Variables on annual changes in the set of relationship banks $(N=158,760)$

At least one additional bank relationship (share)

$0.017 \quad 0$

At least one bank relationship less (share)

$0.017 \quad 0$

Average change in the number of relationship banks

$-0.002 \quad 0$

Annual rate of substitut. of a new relationship bank for an existing one

0.030

\section{Panel B: Firms’ relationship banks}

Main characteristics

Total assets in th. euros

Credit supply in th. euros

Credit supply, growth rate $(N=6623)$

Long-term credit supply, growth rate $(N=5529)$

$\begin{array}{lll}5,817,691 & 488,650 & 55,932,584 \\ 2,287,862 & 267,250 & 16,005,645 \\ 0.026 & 0.018 & 0.080 \\ 0.018 & 0.010 & 0.099\end{array}$

Proprietary trading variables (in th. euros)

Absolute losses from proprietary trading

0.099

Thereof: for banks with proprietary trading losses $(N=284)$

\begin{tabular}{lll}
3623 & 0 & 114,712 \\
84,699 & 400 & 549,368 \\
165 & 0 & 149,350 \\
659 & 100 & 298,498 \\
\hline
\end{tabular}

Thereof: for banks with proprietary trading $(N=1663)$

659

100

298,498

Notes: The firm sample includes 291,079 firm-year observations, and the bank sample includes 6640 bank-year observations for 2006-2010. The bank sample covers all banks that were indicated as a relationship bank by at least one firm in the firm sample and for which information was provided on all variables used in the main estimations. Some of the variables are only available for a subset of firms or banks and years, which leads to a smaller number of observations for these variables, as indicated. We only include firms with more than four employees in the analysis of employment reactions. Standard deviations are unreported for dummy variables. 
Table A2: Bank characteristics by bank type before the crisis

\begin{tabular}{|c|c|c|c|c|c|}
\hline & \multicolumn{2}{|c|}{ "Trading vs. non-trading banks } & \multicolumn{3}{|c|}{ Type of bank } \\
\hline & $\begin{array}{l}\text { Non-trading } \\
\text { banks }\end{array}$ & Trading banks & $\begin{array}{l}\text { Savings } \\
\text { bank }\end{array}$ & $\begin{array}{l}\text { Local } \\
\text { cooper. } \\
\text { banks }\end{array}$ & $\begin{array}{l}\text { Other } \\
\text { private } \\
\text { banks }\end{array}$ \\
\hline Total assets in th. euros & 1,095 & 20,238 & 2,225 & 496 & 11,500 \\
\hline Credit supply in th. euros & 650 & 7,880 & 1,343 & 292 & 4,503 \\
\hline Credit supply to total assets & 0.585 & 0.557 & 0.584 & 0.593 & 0.564 \\
\hline Long-term credit supply in th. euros & 387 & 2,936 & 880 & 178 & 1,647 \\
\hline Long-term credit supply/total assets & 0.352 & 0.344 & 0.381 & 0.363 & 0.321 \\
\hline Share deposits to total assets & 0.876 & 0.852 & 0.886 & 0.870 & 0.861 \\
\hline \multicolumn{6}{|l|}{ Type of bank } \\
\hline Savings bank & 0.162 & 0.610 & 1 & 0 & 0 \\
\hline Local cooperative bank & 0.350 & 0.123 & 0 & 1 & 0 \\
\hline Other private bank & 0.488 & 0.267 & 0 & 0 & 1 \\
\hline Bank-year observations & 1,949 & 625 & 696 & 760 & 1,118 \\
\hline
\end{tabular}

Notes: The table presents mean bank characteristics by bank type. Banks are defined as trading banks if they have nonzero gains or losses from proprietary trading in 2005 and 2006.

Table A3: Firm characteristics by type of relationship banks before the crisis

\begin{tabular}{|c|c|c|c|}
\hline & $\begin{array}{l}\text { Non-trading } \\
\text { banks only }\end{array}$ & $\begin{array}{l}\text { Trading and non- } \\
\text { trading banks }\end{array}$ & $\begin{array}{l}\text { Trading banks } \\
\text { only }\end{array}$ \\
\hline Total assets in th. euros & 5,222 & 31,847 & 15,530 \\
\hline Capital stock in th. euros & 1,187 & 5,882 & 3,045 \\
\hline Capital stock, growth rate & 0.034 & 0.043 & 0.026 \\
\hline Total liabilities in th. euros & 2,365 & 12,648 & 7,121 \\
\hline Ratio of liabilities to total assets & 0.563 & 0.545 & 0.549 \\
\hline Liabilities, growth rate & 0.049 & 0.053 & 0.047 \\
\hline \multicolumn{4}{|l|}{ Variables on relationship banks } \\
\hline Number of banking partners & 1.110 & 2.457 & 1.303 \\
\hline Savings bank & 0.274 & 0.589 & 0.501 \\
\hline Local cooperative bank & 0.301 & 0.352 & 0.066 \\
\hline Other private bank & 0.510 & 0.846 & 0.589 \\
\hline \multicolumn{4}{|l|}{ Industries } \\
\hline Agriculture, forestry & 0.017 & 0.007 & 0.007 \\
\hline Mining and quarrying & 0.001 & 0.001 & 0.001 \\
\hline Manufacturing & 0.181 & 0.263 & 0.182 \\
\hline Energy and water supply & 0.007 & 0.011 & 0.007 \\
\hline Construction & 0.169 & 0.157 & 0.120 \\
\hline Wholesale and retail trade & 0.226 & 0.258 & 0.225 \\
\hline Hotels and restaurants & 0.027 & 0.012 & 0.030 \\
\hline Transport, storage and communication & 0.055 & 0.047 & 0.051 \\
\hline Financial intermediation & 0.015 & 0.011 & 0.017 \\
\hline Renting and business activities & 0.220 & 0.180 & 0.266 \\
\hline Public administration and defense & 0.012 & 0.006 & 0.013 \\
\hline Education & 0.024 & 0.017 & 0.028 \\
\hline Health and social work & 0.046 & 0.031 & 0.054 \\
\hline Firm-year observations & 20,674 & 15,580 & 55,113 \\
\hline
\end{tabular}

Notes: The table presents firms' average characteristics by type of their relationship banks. 
Table A4: First-stage results

\begin{tabular}{|c|c|c|c|c|}
\hline \multirow[t]{2}{*}{ Dependent variable: } & \multicolumn{3}{|c|}{ Lagged credit supply, growth rate } & \multirow{2}{*}{$\begin{array}{l}\text { Lagged long-term } \\
\text { credit supply, } \\
\text { growth rate } \\
\text { (4) }\end{array}$} \\
\hline & (1) & (2) & (3) & \\
\hline $\begin{array}{l}\text { Lagged gains and losses from } \\
\text { proprietary trading over financial assets }\end{array}$ & & $\begin{array}{l}2.422 * * * \\
(0.655)\end{array}$ & $\begin{array}{l}-1.118 \\
(2.107)\end{array}$ & \\
\hline $\begin{array}{l}\text { Absolute value of lagged losses from } \\
\text { proprietary trading over financial assets }\end{array}$ & $\begin{array}{l}-3.028 * * * \\
(0.479)\end{array}$ & & $\begin{array}{l}-5.254^{* *} \\
(2.205)\end{array}$ & $\begin{array}{l}-1.161^{* * *} \\
(0.193)\end{array}$ \\
\hline Losses from proprietary trading (yes=1) & & & $\begin{array}{l}0.087^{*} \\
(0.048)\end{array}$ & \\
\hline D.Business tax rate & $\begin{array}{l}0.160 \\
(0.218)\end{array}$ & $\begin{array}{l}0.154 \\
(0.216)\end{array}$ & $\begin{array}{l}-0.048 \\
(0.261)\end{array}$ & $\begin{array}{l}-0.105 \\
(0.179)\end{array}$ \\
\hline L.D.Business tax rate & $\begin{array}{l}-0.305 \\
(0.220)\end{array}$ & $\begin{array}{l}-0.415^{* *} \\
(0.209)\end{array}$ & $\begin{array}{l}-0.588 * * \\
(0.299)\end{array}$ & $\begin{array}{l}-0.182 \\
(0.205)\end{array}$ \\
\hline Industry-location-size-year fixed effects & $\checkmark$ & $\checkmark$ & $\checkmark$ & $\checkmark$ \\
\hline Tangibility in $2006 \times$ year interactions & $\checkmark$ & $\checkmark$ & $\checkmark$ & $\checkmark$ \\
\hline \# relationship banks in $2006 \times$ year int. & $\checkmark$ & $\checkmark$ & $\checkmark$ & $\checkmark$ \\
\hline Number of observations & 291,079 & 291,079 & 291,079 & 291,079 \\
\hline \multicolumn{5}{|c|}{$\begin{array}{l}\text { Notes: The table presents the first-stage results for the second-stage IV regressions in Table } 2 \text { and Table } 3 . \\
\text { Columns (1) through (3) provide the first stage when overall credit supply is the endogenous explanatory } \\
\text { variable, and column (4) presents the results when long-term credit supply is used instead. Columns (1) and (4) } \\
\text { use the absolute value of losses from proprietary trading as our preferred instrument. Column (2) uses gains } \\
\text { and losses symmetrically in a continuous variable. Column (3) separates the effect of trading gains from the } \\
\text { one of trading losses, demonstrating that trading losses are the relevant instrument to use. D. indicates the first } \\
\text { time difference of a variable, and L. indicates lagged values. The standard errors reported in parentheses are } \\
\text { clustered at the bank level. } * * * / * * * \text { indicate significance at the } 1 \% / 5 \% / 10 \% \text { level. }\end{array}$} \\
\hline
\end{tabular}

\section{Table A5: The role of local labor markets}

2SLS regressions of growth in liabilities, fixed assets and number of employees on growth in credit supply from relationship banks

\begin{tabular}{llll}
\hline \hline Dependent variable: Growth rate of & $\begin{array}{l}\text { Liabilities } \\
(1)\end{array}$ & $\begin{array}{l}\text { Fixed assets } \\
(2)\end{array}$ & $\begin{array}{l}\text { No. of employees } \\
(3)\end{array}$ \\
\hline Low unemployment & $0.217^{* * *}$ & $0.193^{* * *}$ & 0.023 \\
& $(0.067)$ & $(0.055)$ & $(0.036)$ \\
High unemployment & $0.238^{* * *}$ & $0.177^{* *}$ & $0.083^{* * *}$ \\
& $(0.034)$ & $(0.073)$ & $0.101^{* * *}$ \\
Low supply of short-time compensation & $0.315^{* * *}$ & $0.176^{* * *}$ & $(0.032)$ \\
High supply of short-time compensation & $(0.045)$ & $(0.065)$ & 0.003 \\
& $0.138^{* * *}$ & $0.153^{* *}$ & $(0.026)$ \\
\hline
\end{tabular}

Notes: Estimations are at the firm level. Each cell of the table pertains to a separate regression and indicates the elasticity of the outcome with respect to the lagged credit supply from a firm's relationship banks. The regressions follow eq. (2). Due to the smaller samples in these regressions, we do not include industrylocation-size-year fixed effects but rather location-year, size-year and industry-year fixed effects. All estimations are based on the sample for which employment information is available. The lagged growth rate of credit supply is treated as endogenous. All regressions are 2SLS regressions using lagged proprietary trading losses of firms' 2006 relationship banks as the instrument. The standard errors reported in parentheses are clustered at the bank level. ***/** indicate significance at the $1 \% / 5 \%$ levels. 